Article

\title{
How Adding a Battery to Grid-Connected Photovoltaic System Can Increases its Economic Performance: Compare Different Scenarios
}

\author{
Mohamad Kharseh ${ }^{1, *}$, Holger Wallbaum ${ }^{2}$ \\ 1 Chalmers University of Technology; mohamad.kharseh@chalmers.se \\ 2 Chalmers University of Technology; holger.wallbaum@chalmers.se \\ * Correspondence: e-mail@e-mail.com; Tel.: +46-788-67641
}

\begin{abstract}
The current work investigates how adding a battery of optimal capacity to a gridconnected photovoltaic (PV) system can improve its economic feasibility. Also, the effect of different parameters on the feasibility of the PV system was evaluated. The OBC was determined for different saving targets of the annual electricity consumption of the chosen building. For this aim, real electricity consumption data of a residential building in Landskrona, Sweden, was used as energy consumption profile. Solar World SW325XL, which is a monocrystalline solar panel, was selected as PV panels. The calculations were performed under the metrological and economic conditions of southern Sweden. Different working parameters (WP)were considered (prices of the battery, feedin tariffs, and saving targets). The performed calculations show that the optimal battery capacity $(\mathrm{OBC})$, in which the payback time (PBT) of the system is maximized, strongly depends on the WP. The proper selection of the battery can considerably increase the economic feasibility of the PV system in southern Sweden. However, in some cases, using battery can have a negative impact on the PBT of the system. The results show that the electricity price, the module price, the inverter price, and the inverter lifetime have the highest effect on the PBT.
\end{abstract}

Keywords: photovoltaic; optimization; payback time; battery; sensitivity analysis.

\section{Introduction}

Today, most of the global energy used is fossil fuel based [1]. The high fossil-fuel dependence of our current system has resulted in increased atmospheric $\mathrm{CO}_{2}$ concertation from $280 \mathrm{ppm}$ before the industrial revolution to $400 \mathrm{ppm}$ in 2015 [2]. According to the IPCC, the use of fossil fuels is the primary driver for climate change [3]. This manner leads to extreme heat waves, rising sea levels, changes in precipitation resulting in flooding and droughts, intense hurricanes, and degraded air quality, affect directly and indirectly the physical, social, and psychological health of humans. Therefore, a transformation of the global energy systems is needed, and the growth rates of cleanenergy deployment need to be increased. Facing those challenges and achieving the EU targets for $2020^{1}$ and $2050^{2}$, a much faster and widespread utilization of the available local renewable energy resources is required.

Although the current efficiency of the photovoltaic systems is still relatively small and the upfront cost is high $[4,5]$, the abundance of solar energy that strikes the Earth continuously makes such systems a viable alternative. Growing demand for renewable energy sources in recent years, mainly triggered by various regulative frameworks, such as the energy feed-in tariffs in Germany or the Energy Performance Building Directive (EPBD) of the European Union, led to significant

\footnotetext{
${ }^{1} 2020$ climate \& energy package: ec.europa.eu/clima/policies/strategies/2020_en

${ }^{2} 2050$ Energy Strategy: ec.europa.eu/energy/en/topics/energy-strategy-and-energy-union/2050-energy-strategy
} 
reductions in PV costs due to advancing the manufacturing of solar cells [6]. Over the past few years, the price of solar systems has dropped considerably, to the point where such a system can compete with other renewable resources, e.g., wind energy. The fast decrease in system prices combined with the increases in its performance make photovoltaic systems (PVs) resulted in an increased amount installed globally [7]. Regarding the worldwide installed capacity, solar photovoltaic is now the third largest renewable energy source with global demand reached $78 \mathrm{GW}$ installed new capacity [8-10] with a total installed capacity of $303 \mathrm{GW}$ in 2016 [7, 11]. Because it has no moving parts, PV systems $(\mathrm{PVs})$ are stable with the time with a durability of 25 years and low maintenance is required during the operation [9].

In grid-connected PV systems, which are the most common PV systems Europe, the electric network is used as virtual energy storage. Explicitly, when the power generation of the PV system surpasses the requirements of the building, the system will export the excessive PV generation into the grid. Conversely, when the production of the PV system does not cover the request of the building, the system will import electricity from the network. Utilizing the electric grid as energy storage in return reduces the up-front cost of the PV system. Conversely, in some countries, the governmental subsidies on the PV systems are decreasing, in term of reducing the feed-in tariff compared to the electricity purchase price. Hence, minimizing the PV energy injection into the utility network, i.e., rise self-consumption can increase the feasibility of such systems [12]. Fortunately, the battery manufacturing and technologies have been developing quickly, which leads to dramatic reductions in their prices. Thus, the investigation of PV systems combined with batteries has been addressed in numerous studies [6, 7, 12-19]. Islam et at., for example, showed a possibility to use a battery with a PV system with a minimum power loss [19]. Besides improving the economic performance [11], adding a battery to a PV system can contribute to solving the problem associated with the peak energy consumption periods [20]. The economic feasibility of PV systems strongly relies on its upfront cost. Hence, using a battery with the system raises the costs of the system, which can reduce its profitability. Consequently, the definition of the optimum capacity of a battery is a crucial challenge to be addressed in order to enhance the viability of the PV system. Based on the available solar energy and energy consumption, Hesse et al. defined a cost-optimal size of a battery [21]

The effect of using the batteries on the self-consumption depends on the electricity demand profile [18]. At the same time, increasing the self-consumption of a PV system results in benefits to the community and industry by reducing the investments in the electricity network [22]. The study, thus, focuses on three aspects. The first one is to illustrate how using a battery with the PV system can enhance the financial performance, in the term of reducing its payback time and increasing the self-consumption level. The second goal is defining the optimal capacity of the battery as a function of different settings of working conditions. The third goal demonstrates the impact of the uncertainty in some inputs factors on the results obtained from the simulation model.

\section{Methodology}

To achieve the objectives of the current work, real energy consumption data of a residential building in Landskrona $\left(55.87^{\circ} \mathrm{N}, 12.83^{\circ} \mathrm{E}\right)$, in southern Sweden, were used for the analysis. The chosen structure is a multi-story building of the total area of $2972 \mathrm{~m}^{2}$. A computer model was developed to mimic the energy and economic performance of the grid-connected rooftop PV system in which the module elements are attached to the roof of the building. The model was built based on the well-known relationships to calculate PV systems, which were tested in some studies [23-27]. Due to the stability of the monocrystalline PV technology in comparatively cold climate [19], the Solar World SW325XL (monocrystalline based), was selected as candidate PV panels. The optimization of the system was determined by using the built-in solver algorithm in Visual Basic for Applications ${ }^{3}$. The calculations were performed for different scenarios including 1) different price of the battery, 2) different feed-in tariff, and 3) different system size (i.e., annual saving target). The sensitivity analysis

\footnotetext{
${ }^{3}$ Excel VBA reference: docs.microsoft.com/en-us/office/vba/api/overview/excel
} 
was carried out to demonstrate the impact of the various parameters on the feasibility of the system. The considered factors in this study were assumed to vary $25 \%$ higher and lower than the nominal values collected from different resources.

\subsection{Electricity Consumption of the Case Study}

The case study composed of four residential buildings located in Koppargården, Landskrona ( $55.89 \mathrm{~N}, 12.85 \mathrm{E})$. The total roof area of the building is $2972 \mathrm{~m}^{2}$. The electricity consumption between January and December 2015 was collected from the site n4.opendomo.com and illustrated in Figure 1. The annual electricity consumption is $356 \mathrm{MWh}$.

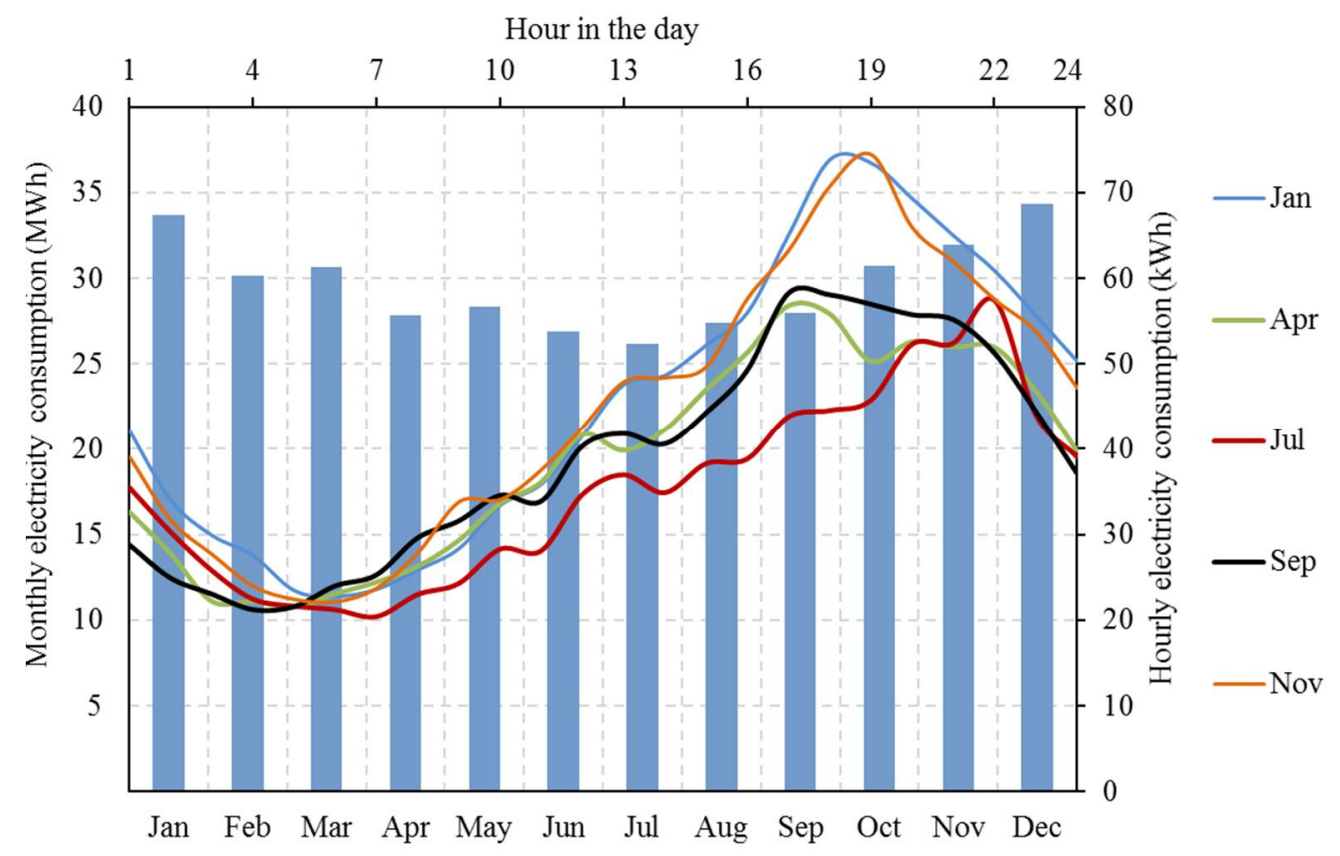

Figure 1. Hourly and monthly average electricity demand of the selected building.

\subsection{Determination of Available Solar Energy}

The first and most important step before designing a photovoltaic system is the determination of the available solar energy (ASE) on an inclined surface in the considered site. ASE can be either measured or simulated. Solar radiation simulations have advantages over measurements and are more reliable over the years [28]. Unlike measured solar radiation, simulated solar radiation can account for universal climate variations over many years, without having the burden of having to process decades of field data. Also, the actual measurements of the ASE are costly due to the high price of the required instruments. Therefore, simulation is a common method to calculate the available solar energy at a particular location. In this work, a computational model was built to estimate the available solar energy, with the resolution of one hour, per square meter of surface considering different slope and azimuth angles. The model can be used to determine the optimal azimuth and slope angles of the PV modules. The optimum angles are defined as the angles that result in maximum annual electricity generation. The metrological working conditions and the clearness index of the city of Landskrona were taken from Refs. [29, 30].

\subsection{Design of the system}

Because the buildings in Landskrona are connected to the electricity grid, this work considers the grid-connected PV system. In such an arrangement, the utility network is used as virtual energy storage, which can reduce the upfront costs of the PV system. Still, the electricity output of the PV system fluctuates as the sun passages through the sky during the day. Consequently, there may be times when the energy generation of the PV system exceeds the power needs of the building or 
conversely. Therefore, in the current study, the electricity demand of the building is met by a combination of solar energy and grid electricity. In other words, when the generation of PV system exceeds energy requirement, the system will inject the excessive PV generation into the grid. Conversely, when the production of the PV system does not cover the request of the building, the system will import electricity from the network. However, since there is a difference in electricity purchase price and feed-in tariff, there might be an advantage in using a battery with the system. Therefore, the design of the system was assessed with and without the use of a battery and for different saving targets in the annual energy consumption of the case study. This way the benefit of using a battery with a grid-connected PV system was demonstrated. Figure 2 shows the scheme of the proposed grid-connected PV system.

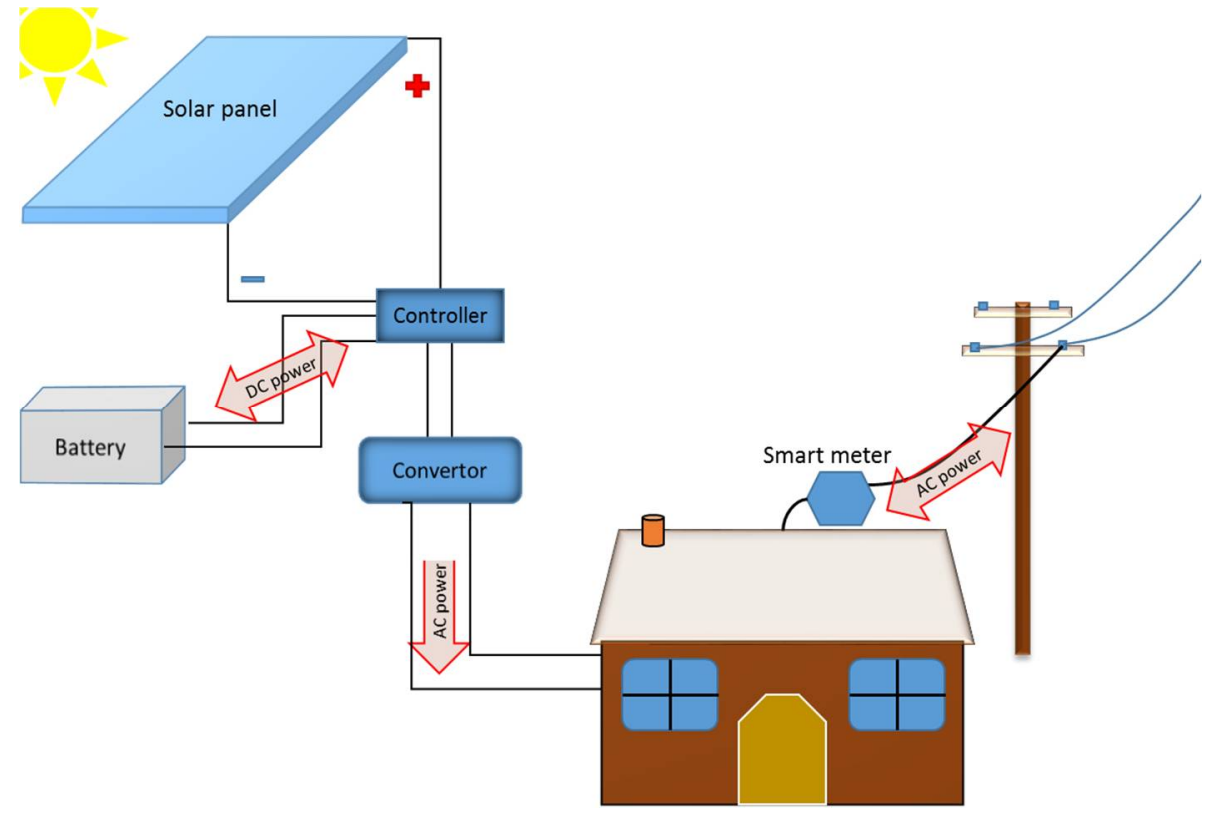

Figure 2. A scheme of the proposed grid-connected PV system.

In this work, a computer model was built to simulate the energy and economic performance of grid-connected rooftop PV system with the resolution of one hour. The model was built on wellestablished equations of designing PV systems that have reported in many published papers [23-26]. The elasticity output per a single PV panel per hour ' $\mathrm{i}$ ' over a year, $\mathrm{P}_{\mathrm{m}, \mathrm{i}}$, is calculated as:

$$
\mathrm{P}_{\mathrm{m}, \mathrm{i}}=\mathrm{FF} \cdot \mathrm{DF} \cdot \mathrm{I}_{\mathrm{sc}-\mathrm{act}} \cdot \mathrm{V}_{\text {oc-act }} \text {, }
$$

Where FF is the fill factor and obtained from the technical sheet of the PV module; DF is derating factor which accounts for all losses throughout the system including module mismatch, module production tolerance, dust/soiling, and wiring, see Table 1 . DF is especially crucial in working conditions of Doha where large amounts of dust and sand can be deposited; Isc-act is the actual short circuit current; $\mathrm{V}_{\text {oc-act }}$ is actual open circuit voltage. Isc-act and $\mathrm{V}_{\text {oc-act }}$ were approximated will by Ref. [27] and given as:

$$
\begin{gathered}
\mathrm{I}_{\mathrm{sc}-\mathrm{act}}=\mathrm{I}_{\mathrm{sc}} \cdot \frac{\mathrm{G}_{\mathrm{s}, \mathrm{i}}}{\mathrm{GsCT}^{\prime}} \\
\mathrm{V}_{\mathrm{oc}-\mathrm{act}}=\mathrm{V}_{\mathrm{oc}}-\frac{\mathrm{VTC}}{1000} \cdot\left(\mathrm{T}_{\mathrm{C}, \mathrm{i}}-25\right),
\end{gathered}
$$

Here $\mathrm{G}_{\mathrm{s}, \mathrm{i}}$ is the available solar energy per square meter $\left(\mathrm{kW} / \mathrm{m}^{2}\right)$ per hour ' $\mathrm{i}$ ' over a year; $\mathrm{Isc}_{\mathrm{sc}} \mathrm{V}_{\mathrm{oc}}$, and VTC are manufacturer's specification of the selected PV (Table 1); Gscr=1000 W solar irradiance at standard test conditions; $\mathrm{T}_{\mathrm{C}, \mathrm{i}}$ is the corresponding temperature of the PV panel. The power generation of a PV panel is strongly related to the module temperature [31], which is a function of the ambient temperature and given by [27]: 


$$
\mathrm{T}_{\mathrm{C}, \mathrm{i}}=\mathrm{T}_{\mathrm{a}}+1.25 \cdot(\mathrm{NOCT}-20) \cdot \mathrm{G}_{\mathrm{s}, \mathrm{i}}
$$

Where NOCT is the nominal operating cell temperature, Table 1; Gs,i represents the hourly available solar radiation on the inclined surface, $(\mathrm{kW})$.

To be able to use the electricity generation of the PV system, an inverter is required to convert the DC (direct current) voltage into grid appropriate AC voltage. Usually, the performance of the inverters depends on the ratio of the real output capacity to the nominal capacity of the inverter. Keep in mind that the electricity output of the PV system fluctuates daily and seasonally, the performance of the inverters varies during the time. In this study, SMA Sunny SB 6000US-10(270), were used as an inverter and Figure 3 [32] shows its efficiency curve. This way, the annual electricity output per a panel of PV, $\mathrm{Em}(\mathrm{kWh})$, can be calculated:

$$
\mathrm{E}_{\mathrm{m}}=\sum_{\mathrm{i}=1}^{8760} \eta_{\text {inverter }} \cdot \eta_{\mathrm{w}} \cdot \mathrm{P}_{\mathrm{m}, \mathrm{i}}
$$

Where $\eta_{\text {inverter }}$ is the efficiency of the inverter (\%), Figure 3, $\eta_{w}$ is the wire efficiency (\%), Table 2. Keep in mind that the PV system will be designed so that the annual electrical energy output of the system equals the required driving energy of the air conditioning system. Thus, the required number of a chosen PV panel $(\mathrm{N})$ is:

$$
\mathrm{N}=\sigma \cdot \frac{\mathrm{E}_{\mathrm{d}}}{\mathrm{E}_{\mathrm{m}}}
$$

Where Ed is required annual electricity $(\mathrm{kWh}), \sigma$ is the annual saving target $(\%)$. Finally, the selfconsumption aspect is usually used to indicate the benefit of integrating the PV system in the utility grid from reduced the stress on the power grid perspective [14]. The self-consumption means the electricity output of the PV that is consumed on site. In this study, the self-consumption, $\phi$, is calculated as:

$$
\phi=\frac{\sigma \cdot E_{d}-E_{\text {fed }}}{N \cdot E_{m}}=1-\frac{E_{\text {fed }}}{N \cdot E_{m}},
$$

Where Efed $(\mathrm{kWh})$ is the amount of generated electricity that is fed into the utility grid and depends on the size of the PV system, the electricity consumption profile, and battery capacity.

As mentioned above, Solar World SW325XL, which is a monocrystalline module, was selected as candidate PV panels. The specifications of the considered PV panel under standard test conditions (STC) are listed in Table 1. These specifications were collected from technical brochures provided by the producer. These specifications were used as the input data and fed to the computer model.

Table 1. Specifications SW325XL panel at standard test conditions.

\begin{tabular}{cc}
\hline Factor & Value \\
\hline Fill factor (FF) & 0.748 \\
Derating factor & 0.891 \\
Short circuit current (A) & 9.48 \\
Open circuit voltage (V) & 46.1 \\
Voltage temperature coefficient (\%/C) & -0.304 \\
Nominal operating temperature (C) & 46.0 \\
Panel capacity (W) & 325 \\
Panel price (US\$) & 310 \\
Area (m²) & 1.995 \\
\hline
\end{tabular}

To be able to use the electricity generation of the PV system, an inverter is required to convert the DC (direct current) voltage into grid appropriate alternating current (AC) voltage. Usually, the performance of the inverters depends on the ratio of the real output capacity to the nominal function of the inverter. Keep in mind that the electricity output of PV system fluctuates daily and seasonally, 
the performance of the inverters varies during the time. In this study, SMA Sunny SB 6000US-10(270), were used as an inverter. The efficiency curve of the selected inverter is shown in Figure 3 [32].

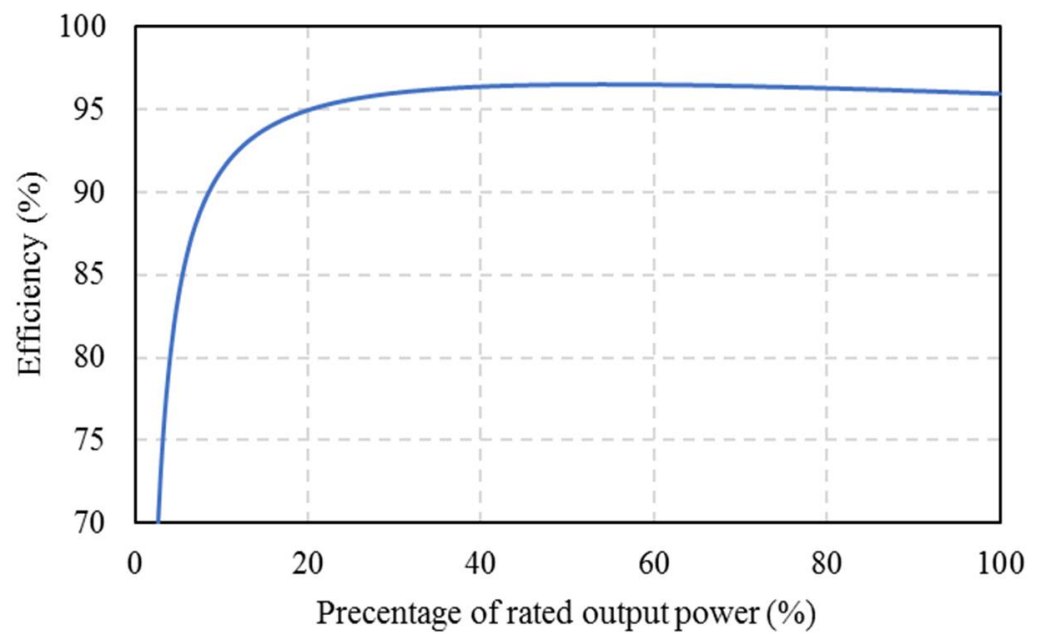

Figure 3. The efficiency of the SMA Sunny SB 6000 inverter along with the capacity ratio

Indeed, electricity savings due to the installation of PV systems can be converted into a monetary value by multiplying the annual energy savings by the price electricity [21]. Hence, the net income of year ' $j$ ' after putting the PV system in service (in USD), i.e., the net cash (Cnet,j) due to installing a PV system is:

$$
\mathrm{C}_{\text {net,j }}=\left(\sigma \cdot \mathrm{P}_{\mathrm{e}} \cdot \mathrm{E}_{\mathrm{d}}-\left(\mathrm{P}_{\mathrm{e}}-\mathrm{P}_{\mathrm{e}, \mathrm{fed}}\right) \cdot \mathrm{E}_{\mathrm{fed}}\right) \cdot(1+\mathrm{er})^{\mathrm{j}}-\mathrm{C}_{\mathrm{O} \& \mathrm{M}, \mathrm{j},}
$$

Where $P_{e}$ and $P_{e, f e d}$ is the current electricity price and feed-in tariff respectively $(\$ / k W h)$, Co\&M,jis the annual cost in year ' $j$ ' which covers operation and maintenance including the replacement of the inverter and the battery (\$/year), see Table 2; er is the annual escalation rate of electricity price. Here it was assumed that the changes in electricity price and feed-in tariff are following the same pattern [11]. Hence, the PV system can be seen as an investment that generates cash. In this study, to aggregate several cash flows, taking into consideration inflows and outflows, cumulative cash flow (CCF) was used [11]. The payback time of the investment is defined as the time required to make the CCF equals zero. The CCF ( $\$$ /year) in the year ' $j$ ' after the system began operating becomes:

$$
\mathrm{CCF}_{\mathrm{j}}=\frac{\mathrm{C}_{\mathrm{net}}}{(1+\mathrm{d})^{\mathrm{j}}}-\mathrm{C}_{\mathrm{inv}}
$$

Where $\mathrm{C}_{\text {inv }}$ is the total front cost of PV system (\$); $\mathrm{d}$ is the nominal discount rate and given by:

$$
\mathrm{d}=(1+\mathrm{g}) \cdot(1+\mathrm{ir})-1,
$$

Where $g$ is the inflation rate; ir is the interest rate, Table 2. While the total up-front cost of PV system was calculated as follows. The price of a PV panel was based on the price given by different suppliers. According to the component prices collected from the literature review, the replacement cost of the inverter (with ten years lifetime) and the labor costs are assumed to be $322 \mathrm{US} \$ / \mathrm{kW}$ and $18 \mathrm{US} \$ / \mathrm{kW}$, respectively [33-35], as listed in Table 2. Mathematically, the upfront cost of a PV system is:

$$
\mathrm{C}_{\text {inv }}=\left(0.340 \cdot \mathrm{P}_{\text {nominal }}+\mathrm{C}_{\text {panel }}\right) \cdot \mathrm{N} \text {, }
$$

Where $\mathrm{C}_{\text {panel }}$ and $\mathrm{P}_{\text {nominal }}$ are the cost and the nominal capacity of a single PV panel, respectively, see Table 1.

As shown above, to simulate the energy and financial performance of the system, assumptions must be made. In this work, the assumptions, which are made based on data collected from a literature review and realistic current conditions, are listed in Table 2 [33-45]. 
Operation and maintenance (O\&M) represent expenses on a system which occur the installation afterward. In this study, the O\&M costs during the first 25 years (which was selected as the project economic life) will be only for the surface cleaning of the PV panels. In the USA in 2013, the cost of supervision and twice a year cleaning of a PV system was reported to be $8.3 \mathrm{US} \$ / \mathrm{kW}$ per year [37]. Therefore, in the current work, the annual O\&M cost for the project is assumed to be $10 \mathrm{US} \$ / \mathrm{kW}$ [36], see Table 2.

Table 2. Assumptions made in the present work

\begin{tabular}{|c|c|c|c|c|c|}
\hline Factor & Value & Factor & Value & Factor & Value \\
\hline inflation rate & $0.79 \%$ & $\begin{array}{c}\text { module } \\
\text { degradation rate }\end{array}$ & $1 \% / y$ & labor cost & $18 \$ / \mathrm{kW}$ \\
\hline real interest rate & $2.5 \%$ & $\begin{array}{c}\text { battery } \\
\text { degradation rate }\end{array}$ & $1 \% / y$ & Operation & $10 \$ / \mathrm{kW} \cdot \mathrm{y}$ \\
\hline Elec. price & $\begin{array}{c}20.7 \\
\mathbb{C} / \mathrm{kWh}\end{array}$ & Inverter lifetime & $9 y$ & $\begin{array}{l}\text { Inverter } \\
\text { efficiency }\end{array}$ & Figure 3 \\
\hline Feed-in tariff & $\begin{array}{c}6.7 \\
\mathbb{C} / \mathrm{kWh}\end{array}$ & Battery lifetime & $8 \mathrm{y}$ & $\begin{array}{l}\text { Battery } \\
\text { efficiency }\end{array}$ & $90 \%$ \\
\hline $\begin{array}{l}\text { Elec. price } \\
\text { escalation rate }\end{array}$ & $2.3 \%$ & $\begin{array}{l}\text { Lifetime of the } \\
\text { project }\end{array}$ & $25 \mathrm{y}$ & Wire efficiency & $98 \%$ \\
\hline Module price & Table $\mathbf{1}$ & Inverter price & $322 \$ / \mathrm{kW}$ & Battery price & $128.3 \$ / \mathrm{kWh}$ \\
\hline & \multicolumn{2}{|c|}{ Cell temperature } & \multicolumn{3}{|c|}{${ }^{4} T_{C}=T_{a}+1.25 \cdot(N O C T-20) \cdot G_{s}$} \\
\hline
\end{tabular}

\subsection{Sensitivity Analysis}

As mentioned, some assumptions were made to simulate the grid-connected PV system. Table 2 shows the nominal value of assumed factors. However, these factors are subject to sources of uncertainty that may affect the accuracy of the results obtained from the simulation model. Therefore, a sensitivity analysis was carried out to show the uncertainty and robustness of the obtained results in the presence of changes in the assumed factors [46]. Table 3 indicates that the considered factors and their ranges (i.e., $25 \%$ higher and lower than the nominal values listed in Table 2). The sensitivity was calculated as the changes in the payback time due to variations in the considered factors.

Table 3. The considered parameter in the sensitivity analysis

\begin{tabular}{cccc}
\hline Factor & Range & Factor & Range \\
\hline Inflation rate & $1.4 \%-2.4 \%$ & labor cost & $13.3-22.5$ \\
Real interest rate & $0.75 \%-1.25 \%$ & O\&M & $7.5-12.5$ \\
Escalation rate of elect. & $0.75 \%-1.25 \%$ & module price & $93.75-156.25$ \\
module degradation rate & $0.75 \%-1.25 \%$ & Inverter price & $241.5-402.5$ \\
Cell tempe. corrector & $\pm 25 \%$ & Electricity price & $6.9-11.6$ \\
Wire efficiency & $97.5 \%-98.5 \%$ & Feed-in tariff & $6.9-11.6$ \\
Inverter efficiency & $(1 \pm 25 \%)$ x each & Inverter lifetime & $7.5-12.5$ \\
& single data point in & & \\
\hline
\end{tabular}

${ }^{4} \mathrm{~T}_{\mathrm{c}}$ is the cell temperature, $\mathrm{T}_{\mathrm{a}}$ is the ambient air temperature, NOCT is the nominal operating temperature, and $\mathrm{Gs}$ is the available solar radiation $\left(\mathrm{W} / \mathrm{m}^{2}\right)$ 


\section{Results and Discussions}

The annual energy consumption of the case study is $356 \mathrm{MWh}$, Figure 1, and the maximum electricity consumption capacity occurs between 17 and 19 o'clock.

As mentioned above, a computational model was built to calculate available solar energy on an hourly basis and the optimal azimuth and slope angles of the PV panels. The ideal inclination angle and azimuth angles in Landskrona, which are defined as the angles in which the available solar energy is maximized, are found to be $47^{\circ}$ and $188^{\circ}$, respectively. The hourly and monthly average available solar energy are listed in Figure 4, while the annual available solar energy of the inclined surface and found Gannual $=1197 \mathrm{kWh} / \mathrm{m}^{2}$. As expected, the results in Figure 4 show that the available solar energy varies from month to month and it is maximized during summertime.

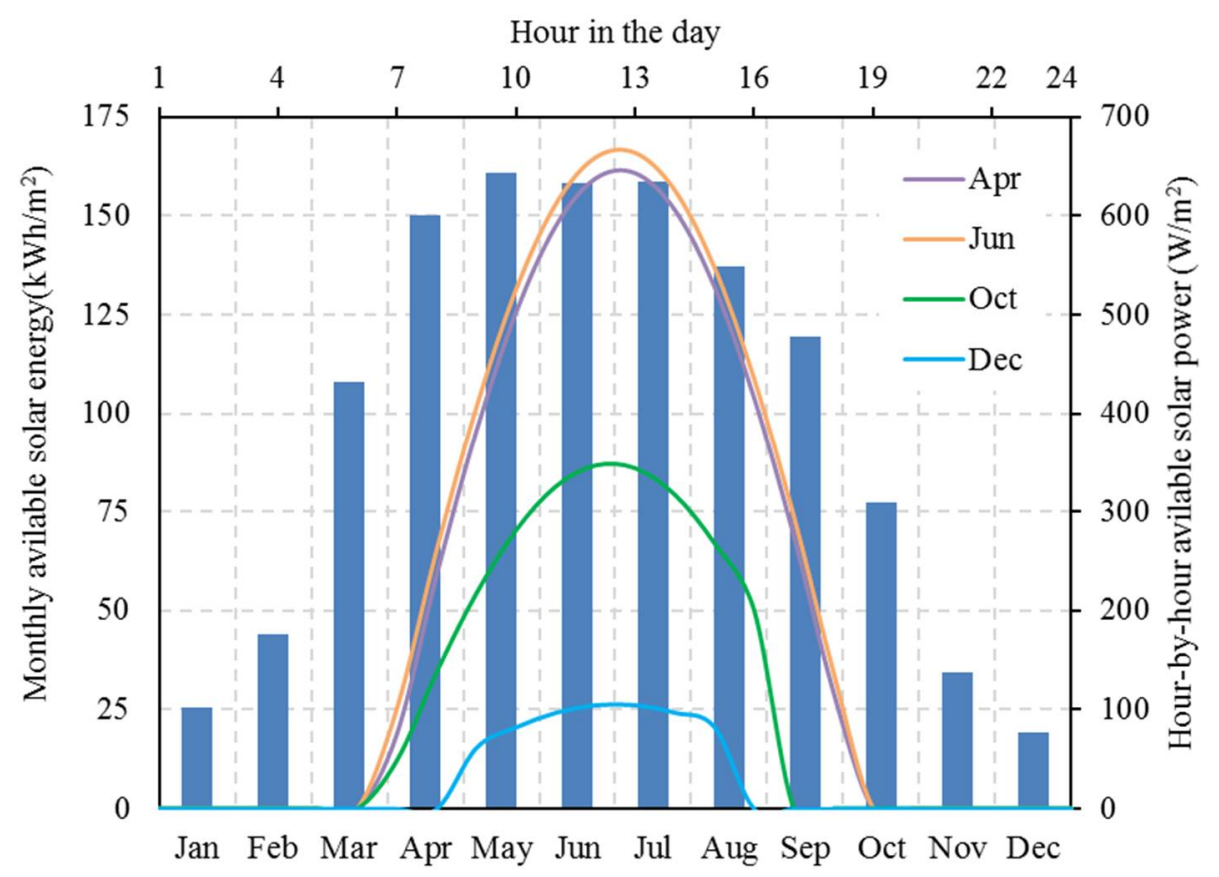

Figure 4. Hourly and monthly available solar energy per square meter on the inclined surface (47 inclination angle and 188 azimuth angle).

Using the computer model, which was built based on the most well-known relationships, the generation per unit area of Solar World SW325XL panel can be determined for each hour in the year. Figure 5 shows the hourly electrical production, as well as the monthly energy generation per a square meter of the selected PV panel. The simulation indicates that the annual energy output per a unit area of Solar World SW325XL is $160 \mathrm{kWh}$. Taking into consideration the results of the existing solar power in Figure 4 and the power generation of the PV panel in Figure 5, the annual effectiveness of the Solar World SW325XL is $13.4 \%$. 


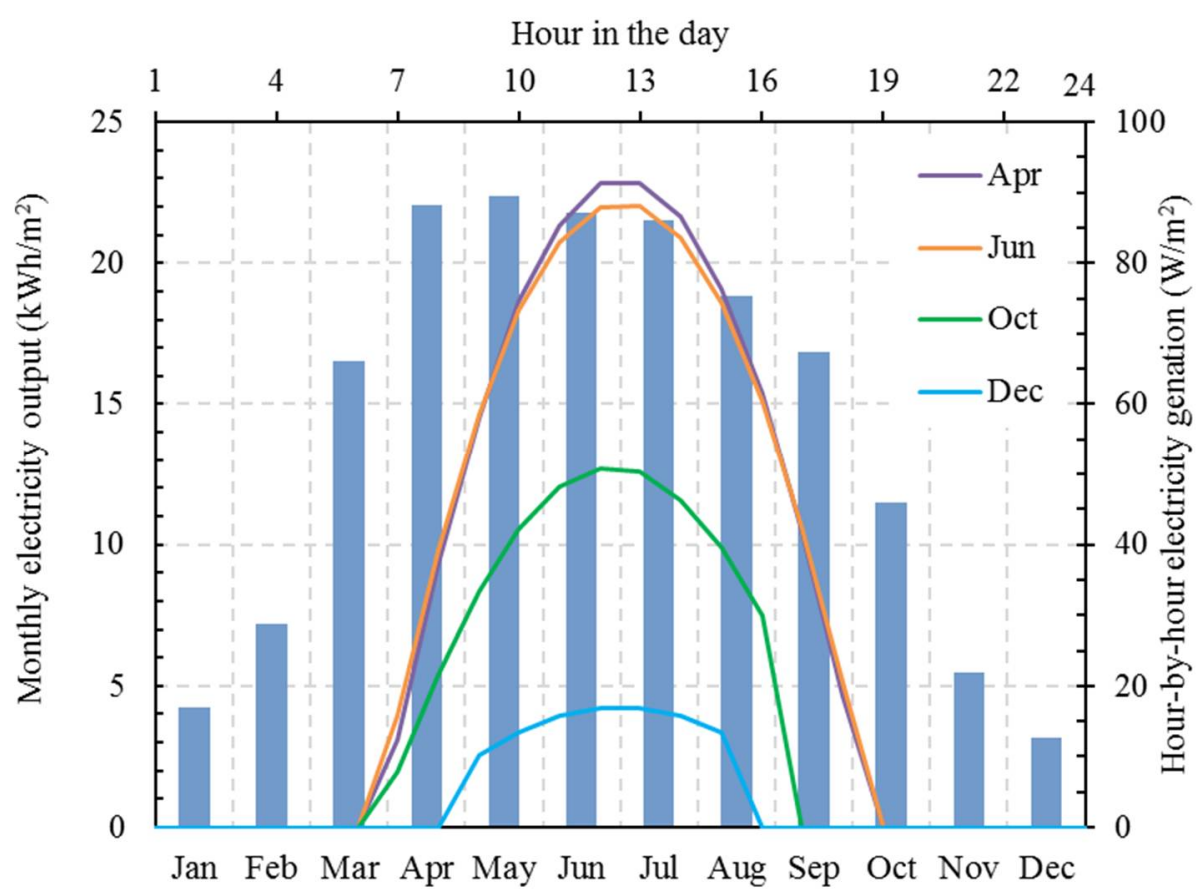

Figure 5. Hour-by-hour power output and monthly energy production per a unit area of Solar World SW325XL on the inclined surface (47 slope angle and 188 azimuth angle).

Figure 6 shows the hour-by-hour average air temperature system of some selected months in the year and the corresponding cell temperature of Solar World SW325XL PV panel. As shown, the higher outdoor air temperate results in higher cell temperature and, consequently, lower efficiency.

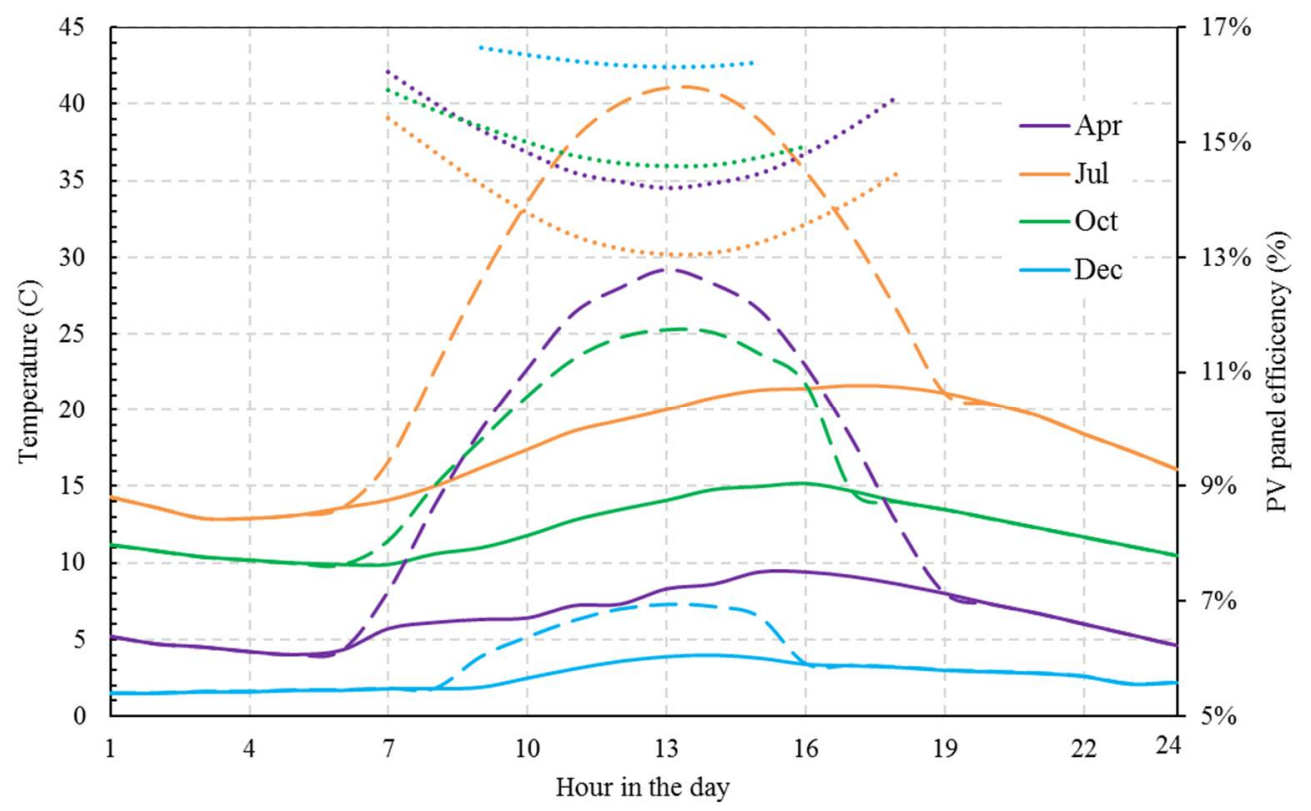

Figure 6. Hour-by-hour average of ( - ) outdoor air temperature, (- - ) the corresponding cell temperature of the PV module, along with (......) the matching PV panel efficiency.

As follows, the number of PV nodule required to meet different saving targets in the annual electricity consumption of the building, $356 \mathrm{MWh}$, can be calculated. Figure 7 shows the required area and number of PV panels to cover different saving targets in the annual energy consumption of the chosen building. Hence, the minimum area required to reach $50 \%$ and $100 \%$, for instance, of the yearly energy needs of the building was found in 1134 and $2310 \mathrm{~m}^{2}$, respectively. Recall that the total 
roof area of the building is $2972 \mathrm{~m}^{2}$, one can say only $38 \%$ and $78 \%$ of the ceiling area is enough to generate $50 \%$ and $100 \%$, respectively, of the annual energy consumption of case study.

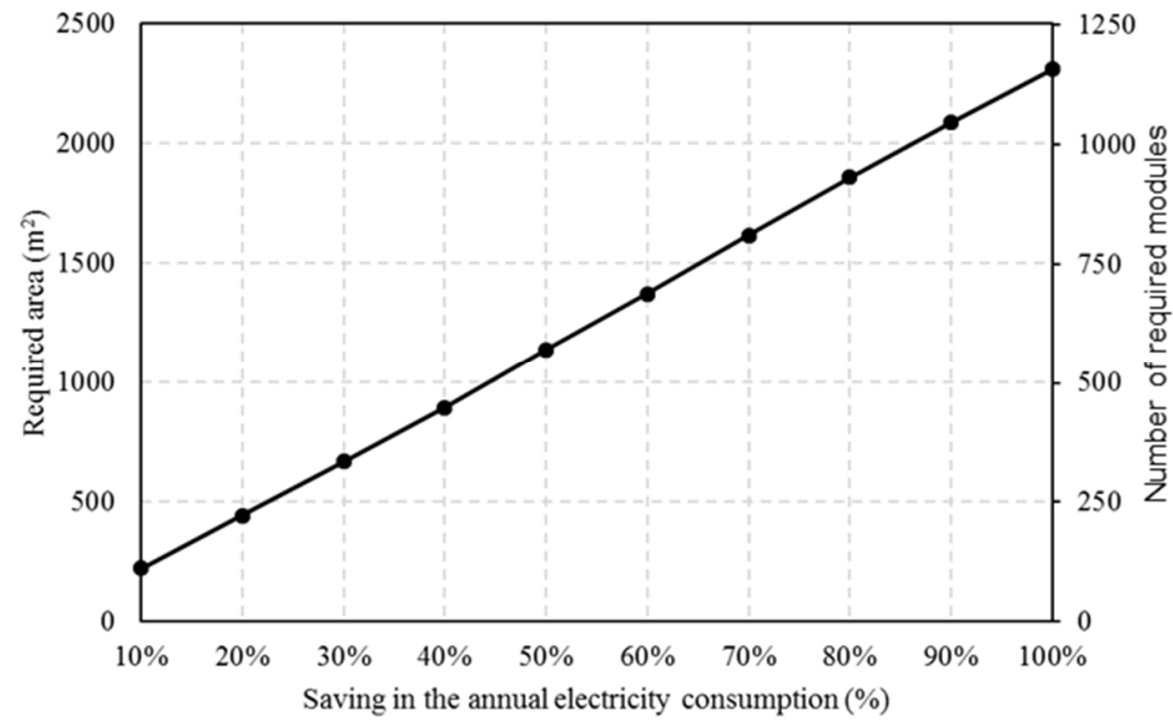

Figure 7 . The required area vs. the saving target in the annual electricity consumptions of the case study

With the electricity consumption profiles illustrated in Figure 1 and the power generation of the panel in Figure 5, there are times when the production of the PV system beats the energy requirements of the building or the vice versa, see Figure 8.

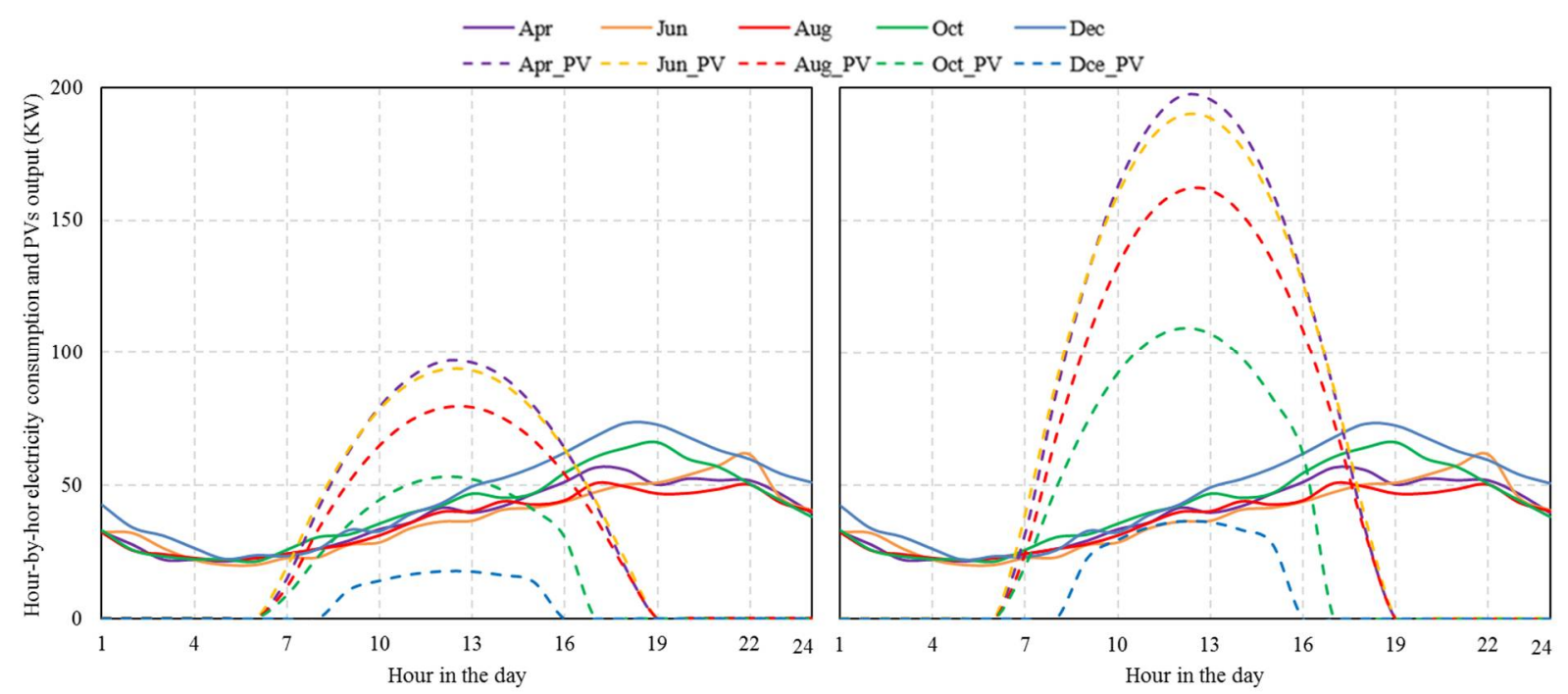

Figure 8. Hour-by-hour daily average of ( - ) energy needs of the buildings and, ( - - ) the power output of the PV system of 50\% saving target (left), and 100\% saving target (right).

Given that, the electric network acts as an energy storage device, which in turn can reduce the upfront expenses of a PV system. However, since the feed-in tariff is smaller than the electricity price, there might be an economic advantage of using a battery with the PV system. Also, adding the battery increases self-consumption of the PV electricity generation and, consequently, reduces the need to purchase electricity from the grid. Increased self-consumption can help to lessen the strain on the distribution grid, which presents another advantage of enhancing the self-consumption. Explicitly, once the generation of the PV system surpasses the needs of the building, the system will use the excessive PV generation to charge the battery and export the excess energy to the grid. Conversely, 
when the production of the PVs does not cover the immediate requirements of the building, the system will import electricity from the battery firstly and from the grid secondly. With the results illustrated in Figure 8, one can see that use a battery will store the excessive electricity generation of the PV system between 7 to 18 o'clock, vary from month to another month, to be used during the peak power, i.e., after 19 o'clock. More details can be seen in Figure 15.

Indeed, the amount of energy that can be stored in the battery and injected into the utility grid depending on many factors including the electricity consumption profile, the power generation profile, the size of the PV system (i.e., the saving target in the annual electricity consumption), and the capacity of the battery. Thus, the advantage of using a battery with the PVs strongly depends on these factors. It is worth pointing out that adding a battery to the scheme rises the advantage of the PV system as mentioned above, but also results in an increased initial cost of the system and increased the electricity losses in due to the losses in the battery itself (i.e., the battery efficiency in Table 2). These disadvantages of using the battery can negatively affect the economic performance of the system. Therefore, there is an optimal capacity of the battery that trade-off the advantages and the disadvantages of using a battery with a grid-connected PV system. In this work, therefore, the calculations were performed for different: 1) price of the battery, 2) feed-in tariff, and 3) system size (i.e., annual saving target). With the results illustrated in Figure 9-12, it can be seen that in some cases using a battery with the PV system improves the financial performance of the system, while in other cases adding a battery can have an adverse impact on the financial performance in term of increasing the payback time of the investment. However, under the working conditions in southern Sweden, adding a battery of high price (i.e., $>400 \$ / \mathrm{kWh}$ ) to a grid-connected PV system always has a negative impact on its economic performance. It is worth mentioning that the nonlinearities of the results presented in Figure 9-12 are due to the way of calculating the payback time and some critical conditions that appear in some cases. It is worth mentioning that the nonlinearities of the results presented in Figure 9-12 are due to the way of calculating the payback time and some critical conditions that appear in some cases. For example, Figure 13 shows the cumulative cash flow (CCF) of a PV with $50 \%$ saving target and feed-in tariff $=3.35 \mathrm{C} / \mathrm{kWh}$ for two different battery size (175 and $250 \mathrm{kWh}$ ). As can be seen in the case of using a battery of capacity $=175 \mathrm{kWh}$ the CCF becomes positing after 15.4 years, which is the PBT of the system. Also, there are two drops in the CCF immediately after the PBT due to the replacement of the battery and the inverter. However, these drops kept the CCF above zero. While in the other case, using a battery of capacity $=225 \mathrm{kWh}$ led to increasing the investment cost and, consequently, the CCF chart is pull down. Thus, two drops in the $\mathrm{CCF}$ sue to the replacement of the battery and the inverter occurred in the negative zone of the $\mathrm{CCF}$, which results in a significant increase in the PBT of the system.
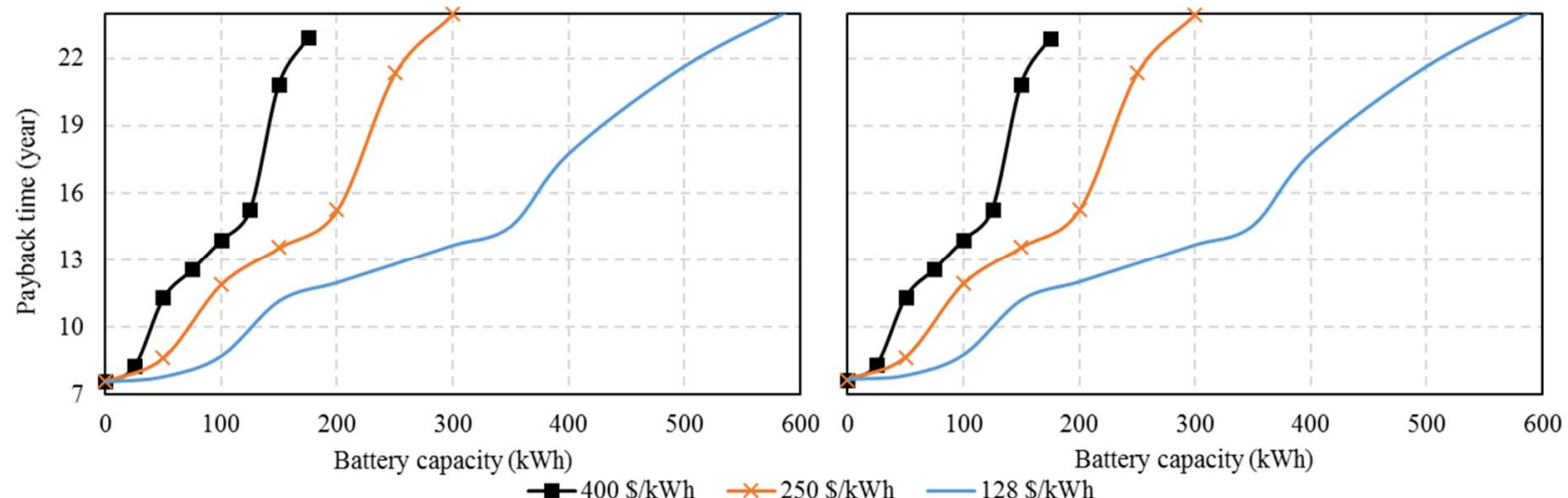

Figure 9. The effect of the battery capacity on the payback time of the PV system for: Feed-in tariff $=6.7 \mathrm{C} / \mathrm{kWh}$ (left), and $3.35 \mathbb{C} / \mathrm{kWh}$ (right). Annual saving target $25 \%$ 

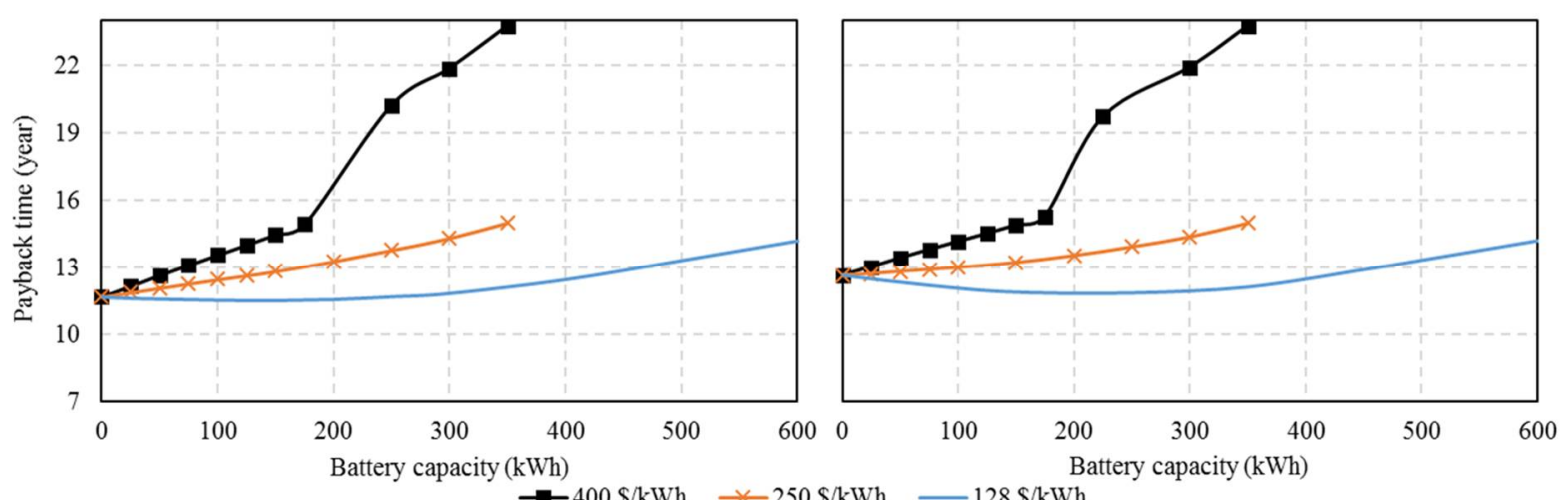

Figure 10. The effect of the battery capacity on the payback time of the PV system for feed-in tariff $=6.7 \mathrm{C} / \mathrm{kWh}$ (left), and $3.35 \mathrm{C} / \mathrm{kWh}$ (right). Annual saving target $50 \%$
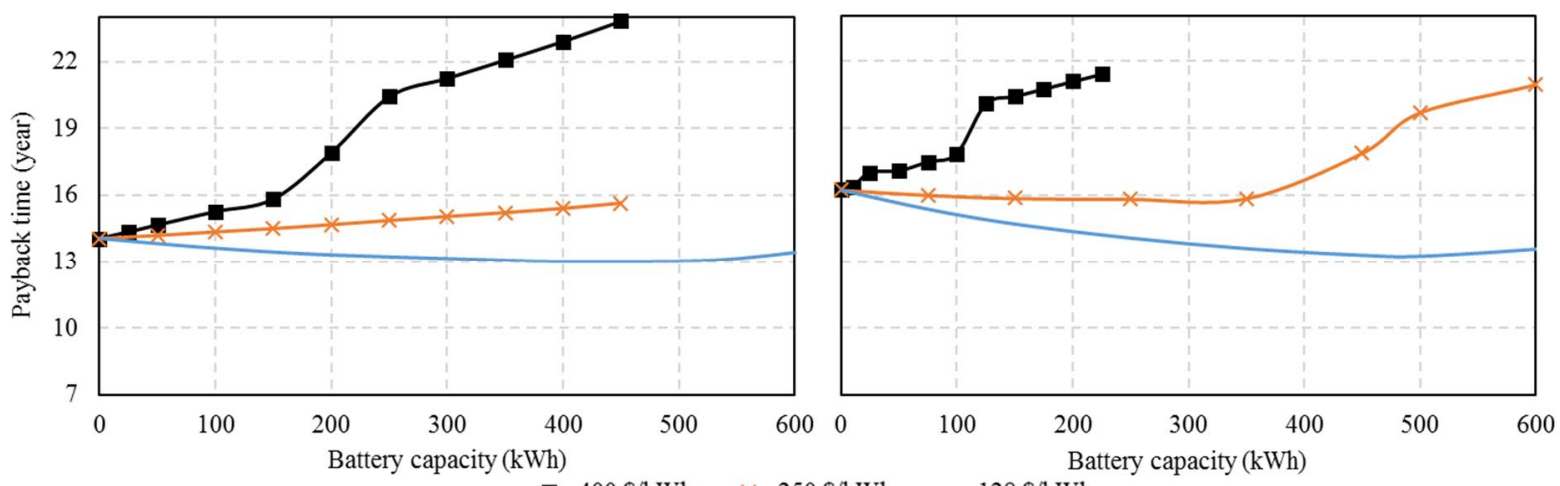

Figure 11. The effect of the battery capacity on the payback time of the PV system for feed-in tariff $=6.7 \mathrm{C} / \mathrm{kWh}$ (left), and $3.35 \mathbb{C} / \mathrm{kWh}$ (right). Annual saving target $75 \%$
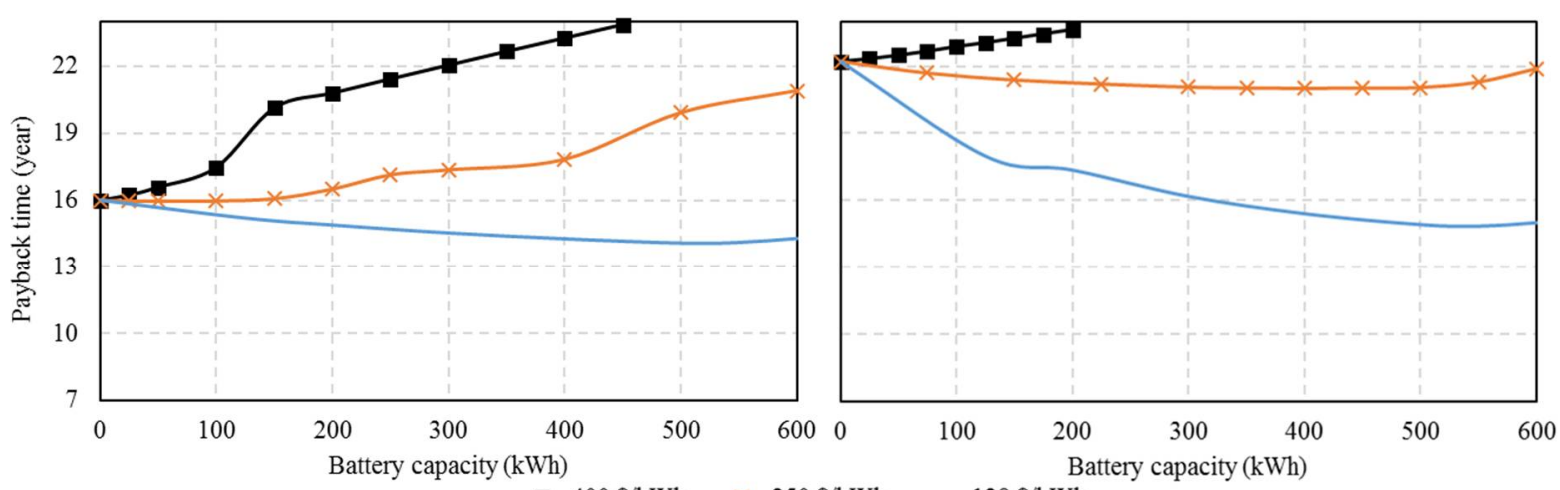

$$
\rightarrow-400 \$ / \mathrm{kWh} \longrightarrow 250 \$ / \mathrm{kWh} \longrightarrow 128 \$ / \mathrm{kWh}
$$

Figure 12. The effect of the battery capacity on the payback time of the PV system for feed-in tariff $=6.7 \mathbb{C} / \mathrm{kWh}$ (left), and $3.35 \mathbb{C} / \mathrm{kWh}$ (right). Annual saving target 100\%. 

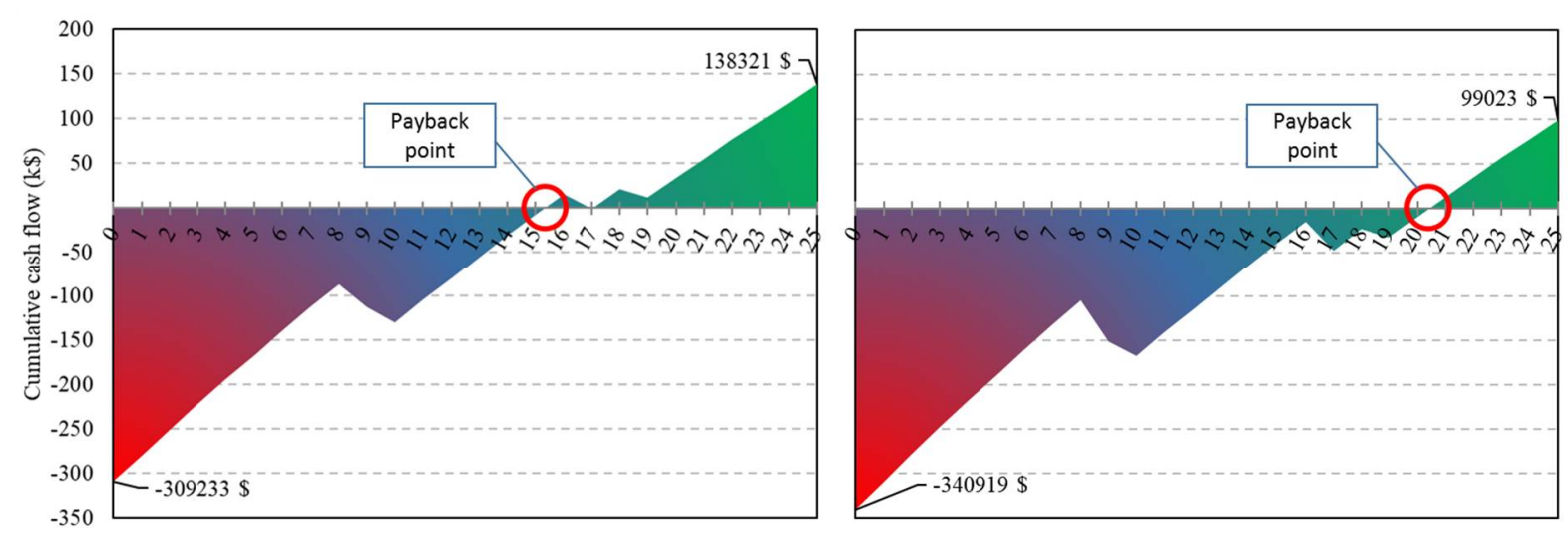

Figure 13. Cumulative cash flow for the PV system with saving target $=50 \%$ and feed-in tariff $=3.34 \mathbb{C} / \mathrm{kWh}$. battery capacity $=175 \mathrm{kWh}$ (left), and $250 \mathrm{kWh}$ (right)

Another important observation can be seen from the results in Figure 9-12 is that the optimal capacity of the battery, which minimizes the payback time of the investment, depends on working conditions including the price of the battery, feed-in tariff, and the saving target. Thus, the simulation was performed for different values of the mentioned parameters to determine the optimal capacity of the battery. As illustrated in Figure 14, for every given working conditions there is an optimum capacity of the battery that can improve the financial viability of the system. Increasing the feed-in tariff, for instance, leads to reduce the optimal capacity of the battery. In the case of the high price of the battery, there is no advantage of using a battery with the PV system in southern Sweden. Also, consistent with the results obtained by Hesse et al. [21], Figure 14 shows for a big local electricity consumption, as compared to the size of the PV system, there is no need to use a battery.

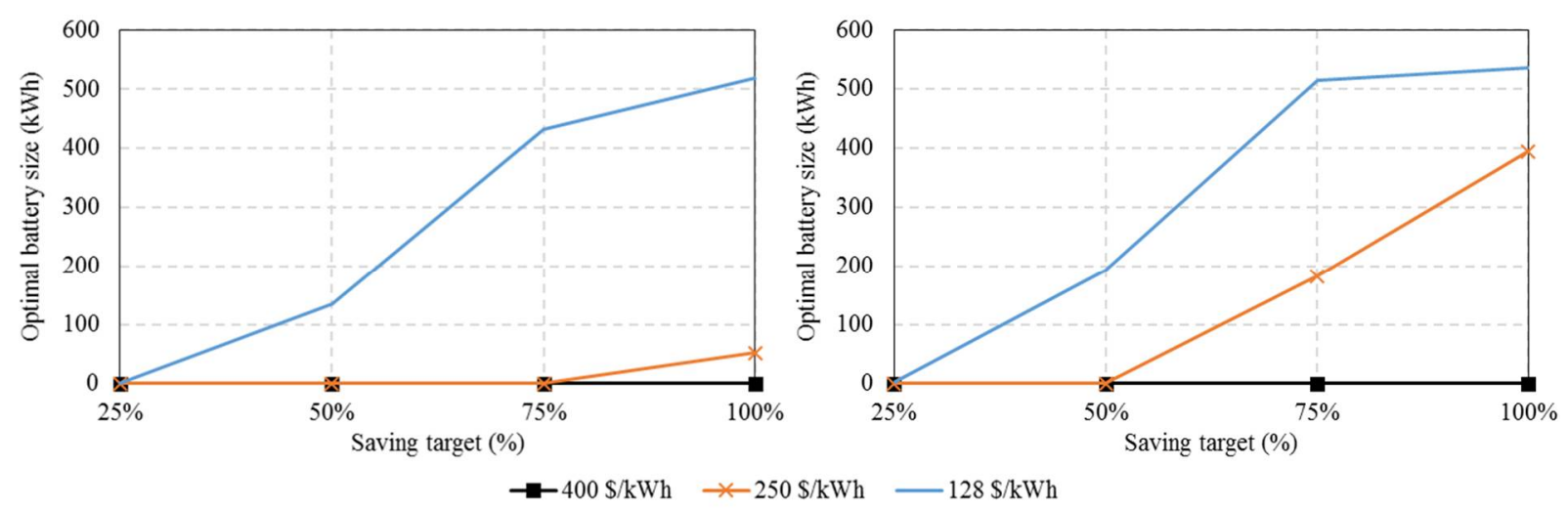

Figure 14. The optimum capacity of the battery along with the saving targets for feed-in tariff $=6.7$ $\mathbb{C} / \mathrm{kWh}$ (left), and $3.35 \mathbb{C} / \mathrm{kWh}$ (right).

Bear in mind the electricity consumption profiles and the electricity output from the panels in Figure 8, there are periods when the output from the PV system exceed the electricity demand of the building or vice versa. Figure 15 shows monthly average electricity consumption, the output of PV system, electricity used from PV output, and electricity fed into the grid for a saving target equals $75 \%$ of the total electricity consumption of the building and two feed-in tariffs ( 3.35 and $0.7 \mathrm{C} / \mathrm{kWh}$ ). As shown above (Figure 14), the optimal capacity of the battery depends on the feed-in tariff, which consequently, affects the electricity fed into the grid. In other words, a lower feed-in tariff results in a bigger capacity of the battery and less electricity fed into the grid. Another conclusion can be drawn from Figure 15 is that in the case of adding a battery to the system, there is a difference between the electricity output of the system and the electricity used (net useful electricity). The difference is due to the loose in the battery during the storing time. This loss depends on the capacity of the battery and its efficiency (see Table 2). 


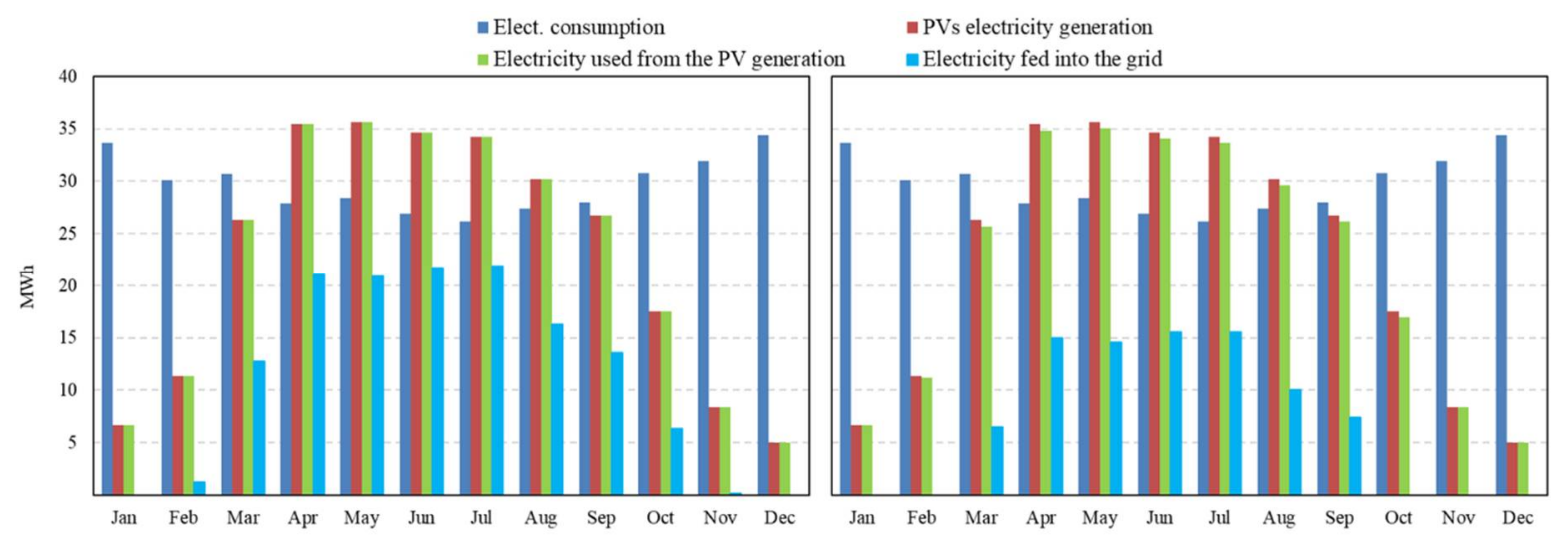

Figure 15. Monthly electricity consumption, the output of the PV system, electricity used from PV output, and electricity fed into the grid. Fore: feed-in tariff $=6.7 \mathrm{C} / \mathrm{kWh}$ and battery capacity $=0$ (left), and feed-in tariff $=3.35 \mathbb{C} / \mathrm{kWh}$ and battery capacity $=183 \mathrm{kWh}$ (right). Annual saving target $75 \%$

To demonstrate the benefit of using the battery, the calculations were performed with and without using a battery of the optimal capacity for different annual saving targets and the results are shown in Figure 16-17. As shown in Figure 16 the reduction in the payback time due to using a battery of the optimal capacity can be up to 7.3 years. Regarding the self-consumption level, the results in Figure 17 show that combining a battery of the optimal size with the PV system can increase the selfconsumption up to $40 \%$ percentage points, which consists with the results obtained by Cucchiella et al. [11]. Increasing the self-consumption has a positive impact on the environment and the utility network when it cannot absorb all production surpluses [11]. Another essential observation from the results is that at the working conditions of southern Sweden using a battery with the PV system improve the economic feasibility of a large system, while for the smaller system there is no benefit of using a battery. Also, the advantage of adding a battery to the scheme is more significant when the gap between feed-in tariff the electricity price is more significant. It is worth mentioning that the reductions in the payback time and the increases in the self-consumption level depending on the load profile of the buildings. Individually, for a given location the benefits of using a battery with a gridconnected PV system vary from building to building as the energy consumption profile be different.

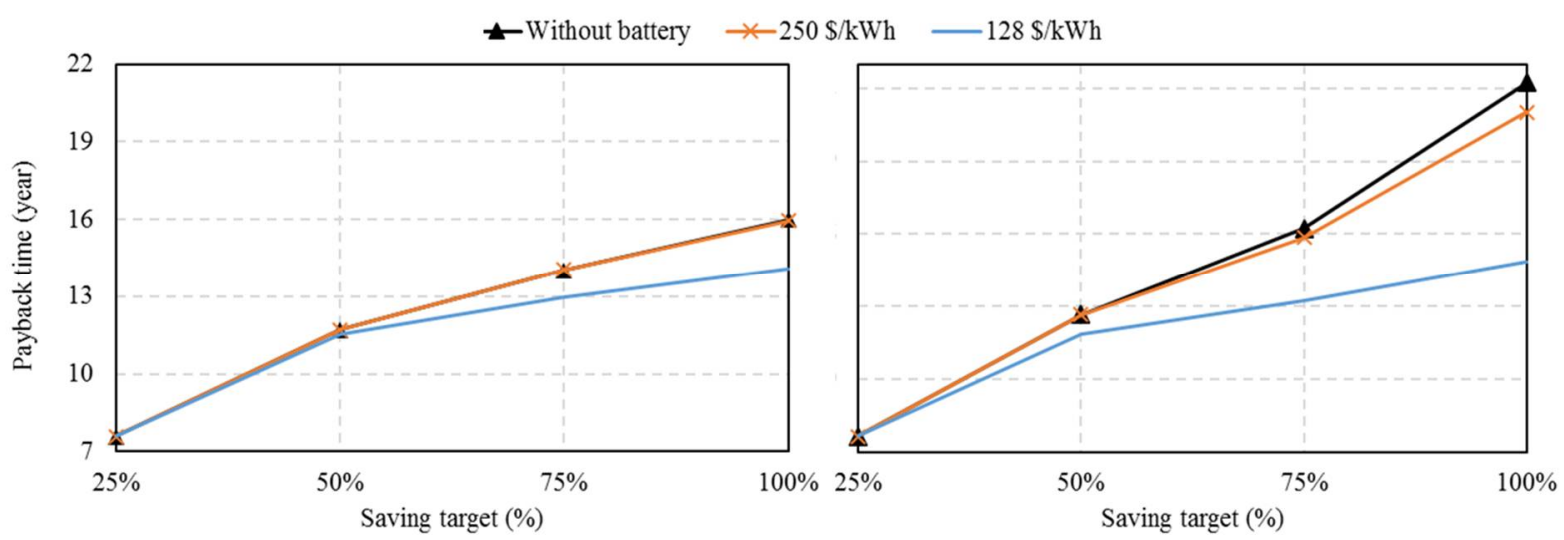

Figure 16. The payback time of the system with and without using a battery of the optimum capacity versus the saving targets for feed-in tariff $=6.7 \mathrm{C} / \mathrm{kWh}$ (left), and $3.35 \mathrm{C} / \mathrm{kWh}$ (right). 

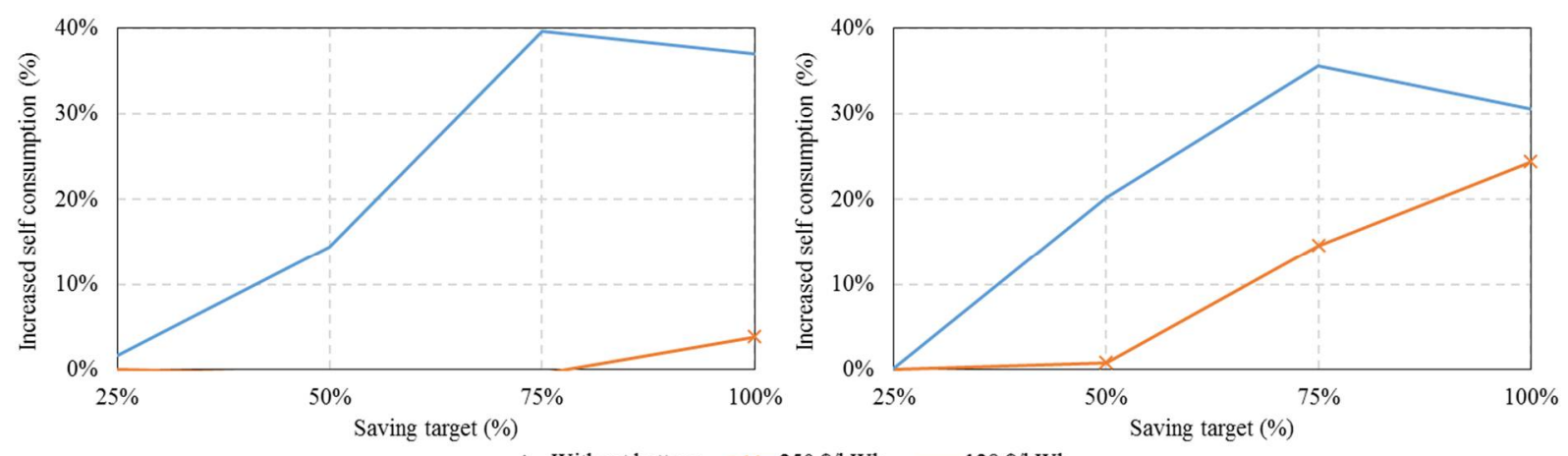

$\rightarrow$ Without battery $\rightarrow 250 \mathrm{~S} / \mathrm{kWh}-128 \mathrm{~S} / \mathrm{kWh}$

Figure 17. Increased the self-consumption percentage points of the PV system due to use a battery of the optimal capacity versus the saving targets, for feed-in tariff $=6.7 \mathbb{C} / \mathrm{kWh}$ (left), and $3.35 \mathbb{C} / \mathrm{kWh}$ (right).

As mentioned above, some assumptions were made to carry out the simulation of gridconnected PVs, which are listed in Table 2. Indeed, these inputs factors are subject to sources of uncertainty that might affect the accuracy of the results obtained from the simulation model. Therefore, a sensitivity analysis was performed with the aim to show the uncertainty and the robustness of the obtained results in the presence of changes in the factors assumed. For this objective, the considered factors in this study were thought to vary $25 \%$ higher and lower than the nominal values shown in Table 2. The simulations were carried out for different saving targets, different battery prices, and various feed-in tariffs, the results are illustrated in Figure 18 and Figure 19. As shown, the impact of uncertainty of the inputs factors on the economic feasibility of the gridconnected PV system in southern Sweden is influenced by the size of the system (i.e., the saving targets), the feed-in tariff, and the price of the battery. However, the electricity price, the module price, the inverter price, and the inverter lifetime seem to be the most critical factors in all cases. The significance of these factors is because the initial cost of the system depends on the components price, while the saving of the system in money term (i.e., cash flow of the system) depends on the electricity price. If the future electricity price, for instance, is $25 \%$ higher/lower than the current rate, the calculated payback time of the PV system will 33-52\% shorter/longer than the calculated ones under the conditions in Table 2. It can also be seen that the effect of the electricity price on the payback time is more significant for a significant annual saving target and low initial cost of the battery. However, the impact of the electricity price is weaker when the feed-in tariff is higher. Another important conclusion can be drawn from the sensitivity analysis is that the influence of the assumed battery price on the feasibility of the PV system is $<4 \%$ in the worst scenario (big saving target, the low assumed cost of the battery and small feed-in tariff). In other words, the influence of the battery cost on the estimated payback time of PV system in southern Sweden can be neglected especially for small PV system and high feed-in tariff. On another side, the impact of module price is more significant for a minor system and independent from other parameters (i.e., the feed-in tariff and battery price).

In a nutshell, one can say that the sensitivity analysis shows that the impact of the uncertainty in some assumptions, such as battery efficiency and inflation rate, on the feasibility of the PV system can be neglected. While it is essential to pay more attention to the electricity price and close consideration must be given to select some components such as inverter and module before carrying out the financial investigation. 

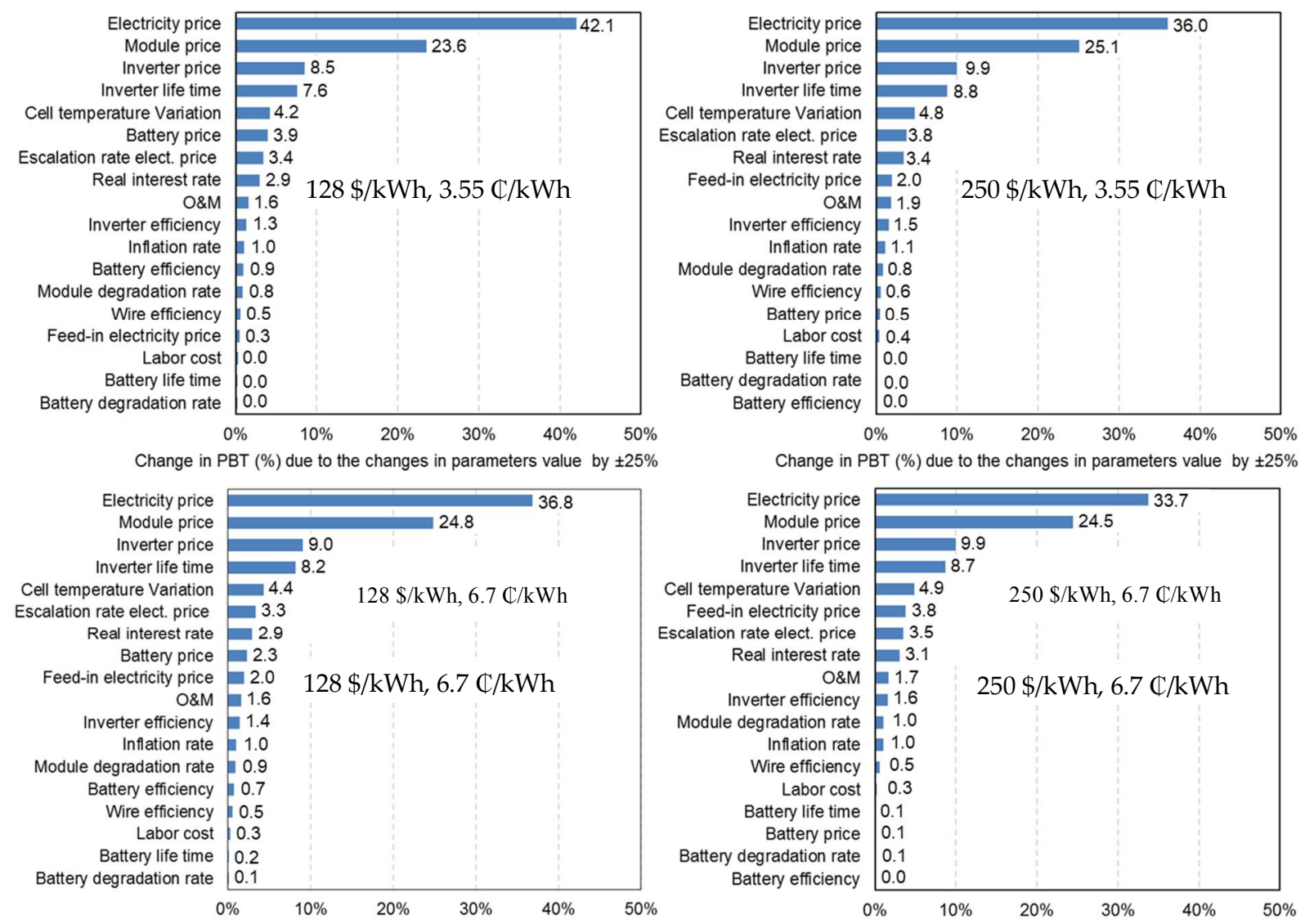

Change in PBT (\%) due to the changes in parameters value by $\pm 25 \%$

Change in PBT (\%) due to the changes in parameters value by $\pm 25 \%$

Figure 18. The impact of different factors in term of relative changes in the Payback time of the PV system for battery price $128 \$ / \mathrm{kWh}$ (left) and $250 \$ / \mathrm{kWh}$ (right). Feed-in tariff: $3.55 \mathrm{C} / \mathrm{kWh}$ (top), and 6.7 $\mathrm{C} / \mathrm{kWh}$ (bottom). Annual saving target 50\% 

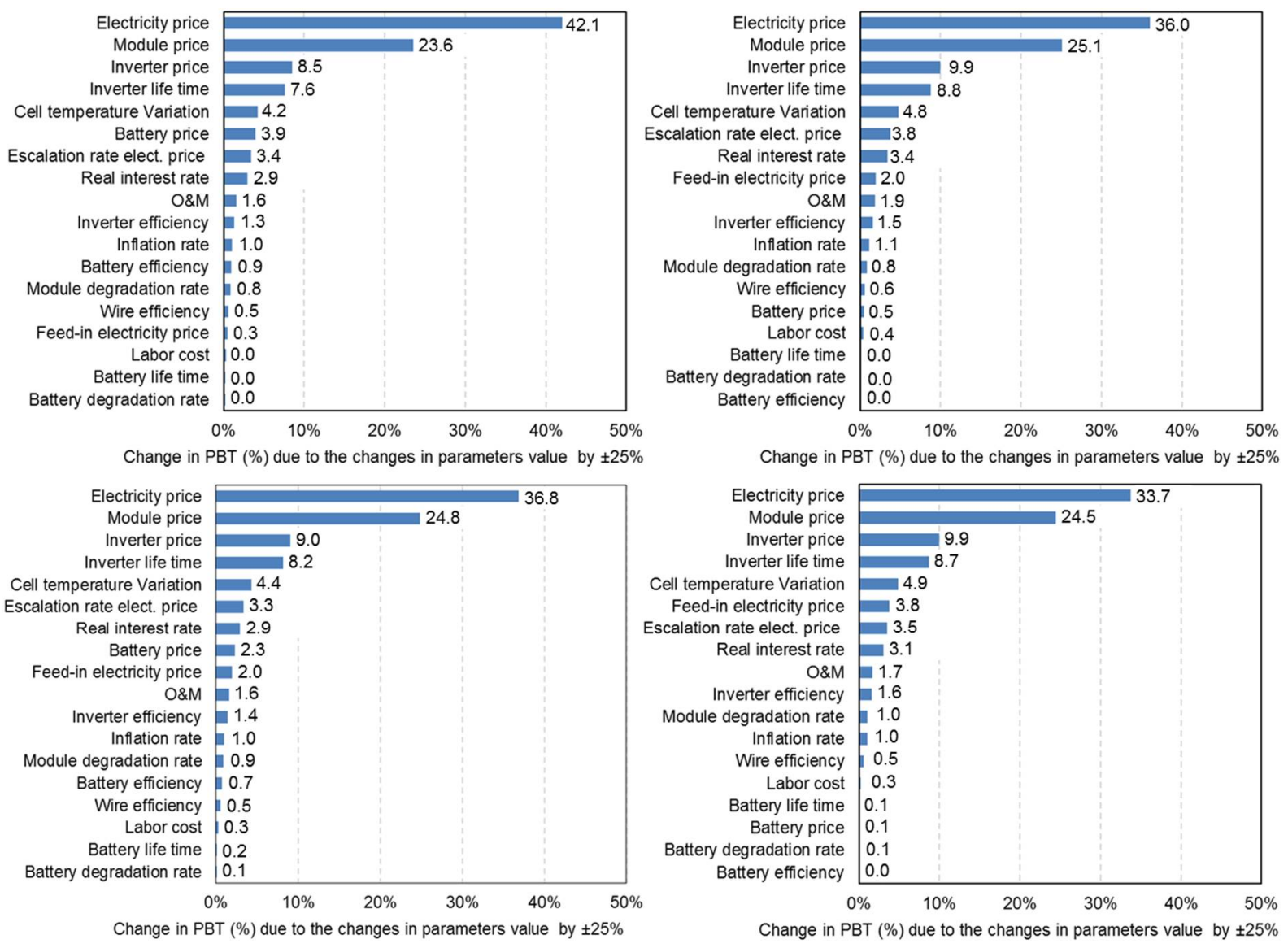

Figure 19. The impact of different factors in term of relative changes in the Payback time of the PV system for battery price $128 \$ / \mathrm{kWh}$ (left) and $250 \$ / \mathrm{kWh}$ (right). Feed-in tariff: $3.55 \mathrm{C} / \mathrm{kWh}$ (top), and 6.7 C/kWh (bottom). Annual saving target $75 \%$.

\section{Conclusion}

The primary objective of this work is to investigate the possibility of improving the viability of a grid-connected PV system in a residential building at the working conditions of southern Sweden. The real energy consumption data of a multi-story residential building, in southern Sweden, of the total area of $2972 \mathrm{~m}^{2}$ was used to generate the electricity consumption profile. A computational model was developed to simulate hour-by-hour the performance of the PV system. The simulation showed that adding a battery to the PV system can significantly improve its performance, in term of reducing the payback time and increasing the self-consumption. While in some cases, it was shown that using a battery with the PV system has a negative impact on the economic feasibility of the system. These mean that the optimal capacity of the batter, in which the payback time of the investment is minimized, strongly depends on the working parameters (WP). Therefore, the calculations were performed for different WP 1) different price of the battery, 2) different feed-in tariff, and 3) different system size (i.e., annual saving target).

Compared to not using a battery, the reduction in the payback time and the increase in the selfconsumption of the PV system can be $>7$ years up to $40 \%$ percentage points, respectively. It is important to mention that increasing the self-consumption results in reduced strain on energy supplies and network.

Sensitivity analysis was performed to show the uncertainty and the robustness of the obtained results in the presence of changes in the different parameters. The simulation showed that the influence of the changes on the results depends on the WP. In General, the results show that the electricity price, the module price, the inverter price, and the inverter lifetime have the most 
significant effect on the accuracy of predicted payback time of the PV system. For example, increase the electricity price by $25 \%$ results in reducing the payback time of the PV system will $33 \%$. While the effect of the change in the feed-in tariff on the payback time of the system can be neglected $(<4 \%$ in the worst case). Another important conclusion can be drawn is that the influence of the assumed battery price on the feasibility of the PV system is $<4 \%$ in the worst scenario (big saving target, the low assumed cost of the battery and small feed-in tariff). Finally, the impact of the uncertainty in some factors, such as battery efficiency and inflation rate, on the payback time of the PV system can be ignored.

\section{Acknowledgments}

The authors are thankful for EC DREEAM (H2020-EeB-2015, GA 680511) project that is supported by Chalmers Area of Advance Energy and funded by the EC.

\section{References}

1. Clerici, A.; Alimonti, G. World energy resources. EPJ Web of Conferences 2015, 98, 01001.

2. Molar-Candanosa, R. 2015 State of the Climate: Carbon Dioxide. National Centers for Environmental Information 2016, .

3. Moomaw, W.; Yamba, F.; Kamimoto, M.; Maurice, L.; Nyboer, J.; Urama, K.; Weir, T. Introduction. In IPCC Special Report on Renewable Energy Sources and Climate Change Mitigation2011, .

4. Bilgili, M. Hourly simulation and performance of solar electric-vapor compression refrigeration system. Solar Energy 2011, 85, 2720-2731.

5. Wrobel, J.; Sanabria Walter, P.; Schmitz, G. Performance of a solar assisted air conditioning system at different locations. Solar Energy 2013, 92, 69-83.

6. Lang, T.; Ammann, D.; Girod, B. Profitability in absence of subsidies: A techno-economic analysis of rooftop photovoltaic self-consumption in residential and commercial buildings. Renewable Energy 2016, 87, Part 1, 7787.

7. Nyholm, E.; Goop, J.; Odenberger, M.; Johnsson, F. Solar photovoltaic-battery systems in Swedish households - Self-consumption and self-sufficiency. Appl. Energy 2016, 183, 148-159.

8. EIA (Energy Information Administration) Annual Energy Outlook2016, DOE/EIA-0383(2010).

9. Taylor, M.; Daniel, K.; Ilas, A.; So, E. Renewable Power Generation Costs in 2014. International Renewable Energy Agency: Masdar City, Abu Dhabi, UAE 2015, .

10. Hill, J.S. GTM Forecasting More Than 85 Gigawatts Of Solar PV To Be Installed In 2017 | CleanTechnica. CleanTechnica Comment Policy 2017, 2017.

11. Cucchiella, F.; D'Adamo, I.; Gastaldi, M. The economic feasibility of residential energy storage combined with PV panels: The role of subsidies in Italy. Energies 2017, 10.

12. Luthander, R.; Widén, J.; Nilsson, D.; Palm, J. Photovoltaic self-consumption in buildings: A review. Appl. Energy 2015, 142, 80-94.

13. Thygesen, R.; Karlsson, B. Simulation and analysis of a solar assisted heat pump system with two different storage types for high levels of PV electricity self-consumption. Solar Energy 2014, 103, 19-27.

14. Luthander, R.; Widén, J.; Munkhammar, J.; Lingfors, D. Self-consumption enhancement and peak shaving of residential photovoltaics using storage and curtailment. Energy 2016, 112, 221-231.

15. Mulder, G.; Ridder, F.D.; Six, D. Electricity storage for grid-connected household dwellings with PV panels. Solar Energy 2010, 84, 1284-1293.

16. Castillo-Cagigal, M.; Caamaño-Martín, E.; Matallanas, E.; Masa-Bote, D.; Gutiérrez, A.; Monasterio-Huelin, F.; Jiménez-Leube, J. PV self-consumption optimization with storage and Active DSM for the residential sector. Solar Energy 2011, 85, 2338-2348.

17. Kharseh, M.; Wallbaum, P.H. The effect of different working parameters on the optimal size of a battery for grid-connected PV systems. Energy Procedia 2017, 122, 595-600.

18. Klingler, A.-.; Schuhmacher, F. Residential photovoltaic self-consumption: Identifying representative household groups based on a cluster analysis of hourly smart-meter data. Energy Effic. 2018, 11, 1689-1701. 
19. Islam, H.; Mekhilef, S.; Shah, N.B.M.; Soon, T.K.; Seyedmahmousian, M.; Horan, B.; Stojcevski, A. Performance evaluation of maximum power point tracking approaches and photovoltaic systems. Energies 2018, 11.

20. Subramani, G.; Ramachandaramurthy, V.K.; Padmanaban, S.; Mihet-Popa, L.; Blaabjerg, F.; Guerrero, J.M. Grid-tied photovoltaic and battery storage systems with Malaysian electricity tariff - A review on maximum demand shaving. Energies 2017, 10.

21. Hesse, H.C.; Martins, R.; Musilek, P.; Naumann, M.; Truong, C.N.; Jossen, A. Economic optimization of component sizing for residential battery storage systems. Energies 2017, 10.

22. Bouly de Lesdain, S. The photovoltaic installation process and the behaviour of photovoltaic producers in insular contexts: the French island example (Corsica, Reunion Island, Guadeloupe). Energy Effic. 2018, , 1-12.

23. Yoon, K.; Yun, G.; Jeon, J.; Kim, K.S. Evaluation of hourly solar radiation on inclined surfaces at Seoul by Photographical Method. Solar Energy 2014, 100, 203-216.

24. Duffie, J.A.; Beckman, W.A. Solar engineering of thermal processes, Wiley: 2006; .

25. El Chaar, L.; Lamont, L.A. Global solar radiation: Multiple on-site assessments in Abu Dhabi, UAE. Renewable Energy 2010, 35, 1596-1601.

26. Basunia, M.A.; Yoshiob, H.; Abec, T. Simulation of solar radiation incident on horizontal and inclined surfaces. Journal of Engineering Research 2012, 9, 27-35.

27. Al-Sabounchi, A.M.; Yalyali, S.A.; Al-Thani, H.A. Design and performance evaluation of a photovoltaic gridconnected system in hot weather conditions. Renewable Energy 2013, 53, 71-78.

28. Al-Khawaja, M.J. Determination and selecting the optimum thickness of insulation for buildings in hot countries by accounting for solar radiation. Appl. Therm. Eng. 2004, 24, 2601-2610.

29. Tukiainen, M. WwW.gaisma.com, .

30. METEONORM Global Meteorological Database for Engineers, Planners and Education. Meteotest Genossencschaft 2004, V7.0.22.8.

31. Das, U.K.; Tey, K.S.; Seyedmahmoudian, M.; Idna Idris, M.Y.; Mekhilef, S.; Horan, B.; Stojcevski, A. SVRbased model to forecast PV power generation under differentweather conditions. Energies 2017, 10.

32. SAM 2016.3.14 System Advisor Model Version 2016.3.14 (SAM 2016.3.14). National Renewable Energy Laboratory. Golden, CO. Accessed October 31, 2016. https://sam.nrel.gov/content/downloads., .

33. Harder, E.; Gibson, J.M. The costs and benefits of large-scale solar photovoltaic power production in Abu Dhabi, United Arab Emirates. Renewable Energy 2011, 36, 789-796.

34. Khalid, A.; Junaidi, H. Study of economic viability of photovoltaic electric power for Quetta - Pakistan. Renewable Energy 2012, 50, 253-258.

35. Chandel, M.; Agrawal, G.D.; Mathur, S.; Mathur, A. Techno-economic analysis of solar photovoltaic power plant for garment zone of Jaipur city. Case Studies in Thermal Engineering 2014, 2, 1-7.

36. Dalenbäck, J. Personam communication with Jan-Olof Dalenbäck, Professor in Building Services Engineering/Project manager CIT Energy Management AB. Jan-Olof.Dalenback@,chalmers.se2017, .

37. Paudel, A.M.; Sarper, H. Economic analysis of a grid-connected commercial photovoltaic system at Colorado State University-Pueblo. Energy 2013, 52, 289-296.

38. Kaplanis, S.; Kaplani, E. Energy performance and degradation over 20 years performance of BP c-Si PV modules. Simulation Modelling Practice and Theory 2011, 19, 1201-1211.

39. CIA World FactsbookPage last updated on July 15, 2016, .

40. Skoczek, A.; Sample, T.; Dunlop, E.D. The results of performance measurements of field-aged crystalline silicon photovoltaic modules. Prog Photovoltaics Res Appl 2009, 17, 227-240.

41. Sánchez-Friera, P.; Piliougine, M.; Pelaez, J.; Carretero, J.; Sidrach de Cardona, M. Analysis of degradation mechanisms of crystalline silicon PV modules after 12 years of operation in Southern Europe. Prog Photovoltaics Res Appl 2011, 19, 658-666.

42. Flowers, M.E.; Smith, M.K.; Parsekian, A.W.; Boyuk, D.S.; McGrath, J.K.; Yates, L. Climate impacts on the cost of solar energy. Energy Policy 2016, 94, 264-273.

43. Eurostat Statistics Explained Electricity prices for household consumers. Eurostat Statistics Explained , 2016.

44. The Global Economy Sweden: Real interest rate. The Global Economy , 2016.

45. Tom, J.; Alice, L. Personal comunication with JA Energy Co., LimitedSep. 2016, .

46. Passer, A.; Ouellet-Plamondon, C.; Kenneally, P.; John, V.; Habert, G. The impact of future scenarios on building refurbishment strategies towards plus energy buildings. Energy Build. 2016, 124, 153-163. 